\title{
A MEDIAÇÃO DIANTE DO CÁRCERE: OS CASOS DE SOBREVIVENTE ANDRÉ DU RAP E CELA FORTE MULHER
}

\section{THE PRISON'S MEDIATION: SOBREVIVENTE ANDRÉ DU RAP AND CELA FORTE MULHER}

\section{Lua Gill da Cruz*}

"Ela me acusa e o meio de me defender é escrever sobre ela" A bora da estrela - Clarice Lispector

"Na avenida, deixei lá A pele preta e a minha voz

Na avenida, deixei lá A minha fala, minha opinião A minha casa, minha solidão" (Elza SOARES. Mulber do fim do mundo.)

\section{RESUMO}

A produção artística e crítica contemporâneas têm colocado em questão a necessidade de observar perspectivas histórias antes silenciadas, de forma a opor-se e resistir ao apagamento de experiências e vivências de grupos, raças, etnias e cores diversas. Em um país como o Brasil, entretanto, caracterizado por desigualdades sociais gritantes, tal tentativa foi e é marcada pela disjunção e pela mediação. Esta mediação frequentemente é marcada por produções em que o intelectual, branco e da elite, organiza e edita a obra de alguém que testemunha outra vivência, o subalternizado, negro e pobre. Se por um lado a figura do intelectual é central para desvelar e inscrever tais histórias, por outro, a mediação não é imparcial, mas marcada por relações de poder. A proposta deste trabalho é introduzir questões relativas ao conceito de literatura de testemunho, literatura sobre o/do cárcere e analisar dois exemplos de tal literatura, os textos Sobrevivente Andrédu Rap (2002) e Cela forte mulber (2003), de maneira a discutir como os textos se estruturam e problematizam a mediação radical da alteridade entre intelectuais e detentos, os seus impasses éticos e textuais, bem como refletir sobre a dificuldade em estabelecer uma (ou muitas) autoria(s) diante de uma certa apropriação autoral da voz do outro.

Palavras-chave: testemunho; autoria; prisão.

\footnotetext{
* Universidade Estadual de Campinas, Campinas (SP), Brasil. luagillc@gmail.com
} 


\begin{abstract}
The contemporary artistic production and critique has put into question the need to observe different historical perspectives that have been silenced, in order to oppose and resist the obliteration of those experiences lived by different groups, races, ethics, and colors. However, in a country like Brazil, defined by its drastic social inequalities, this attempt was and it is characterized by the disjunction and mediation. This mediation is often characterized by productions in which the intellectual, white and rich, organizes and edits someone else's work, a subaltern, black, poor experience and testimony. If the intellectual figure is central to reveal e subscribe theses histories, in another hand, the mediation isn't impartial, but highlighted by power relations. This article intends to introduce questions about literature of testimony and prison literature and to analyze two examples of literary works about the prison, Sobrevivente André du Rap (2002) and Cela forte mulber (2003), in order to debate how the writings structure and interrogate the radical alterity mediation among intellectuals and inmates, its ethical and textual obstacles, as well and to think about the difficult about stablishing one (or many) authorship when faced to a certain ownership appropriation of someone else's voice.
\end{abstract}

Keywords: Testimony; Autorship; Prison.

\title{
INTRODUÇÃO
}

A produção e a crítica literária têm colocado em questão, já há algum tempo, a necessidade de ouvir perspectivas históricas anteriormente silenciadas, a partir de outros agentes que, contrariando a historiografia tradicional, opõem-se e resistem ao apagamento de suas experiências e vivências. A inscrição do subalternizado se constrói na tentativa de garantir espaços de narração de outras versões da história, antes apagadas e ignoradas, bem como de ter tais produções reconhecidas e legitimadas. As minorias sociais, sejam elas mulheres, negros e negras, transexuais, homossexuais, indígenas e prisioneiros passam a ser consideradas vozes importantes de serem ouvidas, também na literatura. Tal tentativa de inscrição, entretanto, em muitas produções, torna visível o mecanismo da mediação, no qual o intelectual, branco e/ou da elite, organiza e edita a obra de alguém que testemunha outra vivência, o subalternizado, negro e/ou pobre. Se por um lado a figura do intelectual é central para desvelar e inscrever tais histórias, por outro, a mediação não é imparcial. A partir de tais premissas, este artigo tem como objetivo apresentar três eixos principais: inicialmente, introduzirá o conceito literatura de testimonio, observando exemplos particularmente reconhecidos, como as obras de Rigoberta Menchú e de Carolina Maria de Jesus; em segundo lugar apresentará brevemente a produção literária contemporânea brasileira sobre o cárcere; para enfim analisar as obras, de teor testemunhal, Sobrevivente Andrédu Rap (2002) e Cela forte mulber (2003), 
com objetivo de discutir como os textos problematizam a inscrição, nas narrativas, de sujeitos subalternizados.

O debate acerca da inscrição das minorias na produção literária adquiriu espaço, principalmente, nas décadas de 60 e 70, em especial com definição da literatura de testimonio como gênero literário pelo Prêmio Casa das Américas. De acordo com Valéria de Marco, essa literatura será definida como um projeto próprio da Revolução Cubana, que tinha como objetivo estimular "a construção da verdadeira história de opressão de dominação burguesa na América Latina, feita a partir da experiência e da voz dos oprimidos" (2004, p. 44). O conceito seria inaugurado com a obra de Miguel Barnet (1966), Biografia de un cimarrón, o qual narra em primeira pessoa a voz de um ex-escravo; o gênero literário, por sua vez, foi particularmente conhecido a partir da obra de Elizabeth Burgos, Me llamo Rigoberta Menchú y así me nació la conciencia (1983), e do prêmio Nobel da Paz de 1992, concedido à Rigoberta Menchú, ativista guatemalteca indígena do grupo Quiché-Maia e sobrevivente do genocídio indígena.

Uma das principais características do gênero literário é o fato de ele ser marcado pela mediação entre um "narrador de ofício" e um narrador que não ocuparia os espaços até então entendidos como próprios da escrita literária, mas cujas experiências observam perspectivas da história até então silenciadas. Assim, o intelectual teria como função recolher essa voz "subalterna", de forma a reproduzir o discurso deste outro representativo de determinado grupo, comunidade ou classe, o qual não tem acesso à cultura letrada (MARCO, 2004). Além disso, a figura do intelectual, seja ele um jornalista, um antropólogo ou um sociólogo, seria transparente, imparcial. A sua participação seria apagada de maneira a tornar-se porta-voz do testemunho, ao fundir-se com o "outro" (PENNA, 2003; SELIGMANN-SILVA, 2010).

O caso da obra de Burgos, por exemplo, já sinaliza tais questões ao apresentar a autoria, na capa, da intelectual antropóloga, ao mesmo tempo em que se intitula "Me chamo Rigoberta Menchú". Ademais, a narração, estruturada majoritariamente em primeira pessoa, a partir das experiências de resistência e da vida da ativista indígena, também indicam essa pretensa fusão entre a autora e aquela que testemunha. Os procedimentos da escrita, entretanto, são explicitados nos prefácios da obra, em que nos deparamos com informações sobre como as duas se conheceram, como se deu passagem do testemunho oral para o escrito e como ocorreu a constituição e a decisão acerca da estrutura do texto. Durante a escrita, Burgos decidiu "colocar-se no lugar que lhe cabia", escutando e deixando Rigoberta falar e "convertendo-se numa espécie de seu duplo, no instrumento que executaria a 
passagem do oral para o escrito" (BURGOS, 1993, p. 30, grifo meu). A definição de tais obras perpassa hoje, entre outras questões, a crítica à suposta crença de imparcialidade do mediador. Não se pode mais, principalmente a partir dos debates contemporâneos e pós-coloniais, ignorar as diferenças radicais que constituem os dois indivíduos que constroem tais obras. Penna (2003) afirma que essa relação entre "informante e gestor" se estabelece como uma negociação complexa de diferenças entre

discurso oral e escrito, povo e elite, movimentos sociais e intelectual universitário, sujeito subalterno e sujeito letrado, antropologia e literatura, discurso referencial da verdade e discurso auto-referencial do texto, sem que haja fusão ou conciliação possível entre os dois mundos (PENNA, 2003, p. 308).

Logo, os conceitos de autor, autoria e autoridade são construídos sob fraturas que não podem mais ser vistas como imparciais, mas que são imbricadas e expostas. $\mathrm{O}$ narrador entrega o seu relato ao gestor que, ao mesmo tempo em que pode garantir - mediante a sua posição legitimada pela sociedade burguesa - a sua visibilidade e legitimidade, pode tornar-se dono do que é dito, sendo o texto passível, inclusive, de modificações ou manipulações que estejam a serviço das elites.

Em um país como o Brasil, especialmente marcado por desigualdades sociais gritantes, tal tentativa também foi e é marcada pela disjunção e pela mediação entre diferentes classes sociais, raças, gêneros e espaços geográficos. Os casos de Carolina Maria de Jesus - a que se refere o número três da revista Casa de las Americas como testemunho histórico do desamparo e da miséria da população brasileira (SELIGMANN-SILVA, 2010) - e de Stela do Patrocínio são paradigmáticos nesse sentido, pois caracterizam uma produção em que o intelectual, branco e da elite, organiza e edita a obra de alguém que testemunha outra vivência, a subalterna, negra e pobre. Se por um lado a figura do intelectual é central para desvelar e inscrever tais histórias e, portanto, tem a sua importância e relevância garantidas, por outro, a mediação é necessariamente marcada por relações de poder. Esse é o caso das obras aqui referidas: Sobrevivente Andrédu Rap e Cela forte mulher, a que me deterei em seguida.

No caso específico de Quarto de despejo (1960), a mediação da figura de Audálio Dantas, jornalista que ao ir ao Canindé, periferia de São Paulo, descobre e desvela Carolina Maria de Jesus é central. De acordo com o jornalista, ao deparar-se com os cadernos encardidos de Carolina, percebeu que não havia mais ninguém que poderia contar tal história a partir de uma visão até então inédita: "de dentro da favela" (JESUS, 2014, p. 6). Dantas, além de ter descoberto e desvelado a autora - e sem o qual, provavelmente, não teríamos acesso a esse texto essencial para a literatura brasileira -, atribui a si mesmo, no prefácio do livro, o papel de "edição de 
texto", no qual teria feito cortes de maneira a selecionar trechos significativos e teria mexido apenas "na pontuação, assim como em algumas palavras cuja grafia poderia levar à incompreensão de leitura. E foi só, até a última linha" (JESUS, 2014, p. 7). Logo após o prefácio há ainda uma "nota dos editores", que garante a fidelidade à autora, respeitando a linguagem, a grafia e a acentuação das palavras, de maneira a traduzir "com realismo a forma de o povo enxergar e expressar seu mundo" (JESUS, 2014, p.9).

De acordo com Elzira Perpétua, o texto do prefácio de Dantas explicita o imbricamento de coautoria entre ambos, tornando possível a obra final, em que temos, de um lado, a autora "descrevendo a rotina de uma vida miserável e reconstituindo na escrita as reflexões e os sonhos que a moviam" e, de outro, Dantas que "de posse dos manuscritos, procedeu a um minucioso trabalho de editoração, preparando os originais para publicação" (PERPÉTUA, 2002, p. 35). O que ele afirma no prefácio, entretanto, é uma versão bastante reduzida do que foi o processo de editoração. É a figura de Dantas que avalia os manuscritos de Carolina, que a lança como escritora na imprensa e que assina o prefácio. Sem desconsiderar o papel e a importância da produção de Carolina que narra, na sua força, por si mesma, é importante perceber que, diante da mediação, a Carolina a que temos acesso, na sua obra principal, é a que Dantas construiu. Quarto de despejo, inclusive, é um best seller, principalmente, não por seu caráter literário - ao contrário do que pretendia a autora -, mas porque é definido e predeterminado pelo editor na apresentação do volume, como "referencial importante para os estudos culturais e sociais, tanto no Brasil como no exterior" (JESUS, 2014, p. 5). Logo, Dantas privilegia uma perspectiva social e histórica em detrimento de uma valorização literária de Quarto de despejo que importa, defende o mediador, porque apresenta e denuncia, a partir da linguagem do subalterno, as condições sociais do Brasil.

A mediação, entretanto, não é neutra, mas marcada pela vontade de Dantas de criar uma Carolina agradável aos - e filtrada para os - olhos da elite. A partir de uma análise de crítica genética, Perpétua (2014) percebeu que, no processo de editoração, Dantas simplifica o seu papel em uma espécie de "simulacro da transparência", na medida em que não admite a atuação em acréscimos, substituições e supressões que, em geral, tornam a linguagem e as questões de Carolina mais "populares", como, por exemplo, a retirada de trechos em que debate política, discute filósofos, ou a substituição de termos escritos inicialmente na norma padrão da língua. É também Audálio Dantas que mantém o poder de mediação, ao dizer o que cabe como publicação, depois da primeira obra. Luciana Paiva (2015) defende que ele é, assim como quem define o início da carreira de Carolina, quem decide o ponto 
final de sua trajetória. Carolina Maria de Jesus, ao contrário, nos seus escritos e no financiamento próprio das obras posteriores, parece ter certeza do lugar que almeja: a autoria de literatura. A força da escrita literária resiste, apesar das imposições circunscritas de Dantas. A mediação, entretanto, ainda que não necessariamente de forma intencional, a mantém no lugar que acreditava ser o único possível: as margens. Quem sabe consigamos hoje retirá-la (e retirar tantos outros) de tal insígnia e inseri-la no local que almejava.

\section{O TESTEMUNHO DO/SOBRE O CÁRCERE NO BRASIL}

"Habitante daqui é futuro residente da Casa de Detenção. E se os rapazes achavam graça, Lima rematava: - Ou do hospício. - e faziam um ar triste para concluir" (João ANTÔNIO. Malaguetas, Perus e Bacanaço.)

No debate contemporâneo, a questão da mediação permanece atual e, quem sabe, tenha adquirido ainda mais força depois dos debates dos Estudos Culturais e das perspectivas pós-coloniais, bem como da organização e atuação política pelos direitos das minorias nos últimos anos. Internacionalmente, o Prêmio Nobel de Literatura foi dado, em 2015, à escritora, jornalista e historiadora oral Svetlana Aleksiévitch, que constrói as suas obras literárias a partir de um gênero híbrido e composto de entrevistas, mediadas e transcritas pela autora, sobre temáticas diversas e com o olhar atento ao que é apagado pela historiografia oficial.

No Brasil, a questão se situa diante em um debate crescente da inclusão de outras vozes "marginalizadas", "subalternizadas", apagadas e esquecidas, em um país profundamente desigual e marcado pela violência crescente. $\mathrm{O}$ debate se situou, principalmente e mais recentemente, na literatura marginal, e, especificamente, na literatura sobre o cárcere no fim do século XX e início do século XXI, impulsionada, sobretudo, pelo massacre do Carandiru e sua representação na obra de Drauzio Varella, Estação Carandiru (1999), assim como nas adaptações de Hector Babenco em Carandiru: ofilme (2003) e na série televisiva Carandiru: outras histórias (2005). De acordo com João Camillo Penna (2009), perante a experiência do Carandiru, a sociedade brasileira teve de tornar-se consciente da existência da sua "metade criminalizada", a qual escancara a divisão interna do Brasil, mas que, ao mesmo tempo, diante da sua representação e da construção simbólica, da literatura e do cinema, torna visíveis aqueles que seriam "inimigos sociais". As obras evidenciam e permitem um certo enquadramento de vidas que não são nem ao menos consideradas como tal, ou seja, não são "passíveis de luto", o que aumenta ainda mais a sua vulnerabilidade, nos 
termos de Judith Butler (2004, 2015). A condição precária, definida pela filósofa, designa uma situação politicamente instaurada na qual determinadas populações ou grupos são expostos a formas de apoio deficientes e a violações e violências cotidianas. Butler afirma, sobre a relação da precariedade com o Estado, que "a condição precária também caracteriza a condição politicamente induzida de maximização da precariedade para populações expostas à violência arbitrária do Estado que com frequência não têm opção a não ser recorrer ao próprio Estado contra o qual precisam de proteção" (BUTLER, 2015, p. 47).

No ano de 2017, o debate sobre o cárcere e sobre a necessidade de escutar as vozes sobreviventes parece ainda mais relevante. Ano em que a frase "bandido bom é bandido morto" assumiu uma grande importância no debate nacional. Ano em que o massacre do Carandiru completa 25 anos. Ano em que os brasileiros viram - em TV aberta ao vivo - novos massacres nos cárceres brasileiros, no Amazonas, em Roraima e no Rio Grande do Norte, os quais superaram, inclusive, o número de mortos do cárcere paulistano. Tudo isso um ano depois da anulação do julgamento que condenou os 74 policiais militares envolvidos na chacina no cárcere paulistano sendo que, também em 2016, Nuno Ramos, um dos primeiros artistas a se deter sobre o tema do massacre, atualizou a sua obra $111^{1}$ para o que chamou de 111: uma vigília, a qual se organizou em protesto à anulação, com artistas e ativistas reconhecidos lendo, durante 24 horas, a lista dos mortos no massacre para uma câmera que transmitia ao vivo pela internet o ato realizado em São Paulo. A performance/ato contou com mais de um milhão de espectadores, ${ }^{2}$ ou seja, as obras literárias e as produções artísticas, ao contrário do sistema judiciário, continuam colocando em pauta o que não pode ser esquecido.

Ao contrário da produção anterior sobre o cárcere, que tinha como foco, principalmente, os presos políticos - o livro Memórias do cárcere (1953), de Graciliano Ramos é um grande exemplo -, os críticos literários demonstram como a produção contemporânea se volta, no início dos anos 2000, para o que seriam "novos escritos do cárcere" (SELIGMANN-SILVA, 2006; PALMEIRA, 2009), a partir do relato das experiências de "presos comuns", ${ }^{3}$ os quais oferecem outras perspectivas da

1. Web site do artista Nuno Ramos. Obra 111. Disponível em: http://www.nunoramos.com.br/portu/ comercio.asp? flg Lingua $=1 \& \operatorname{cod}$ Artista $=92 \& \operatorname{cod}$ Serie $=17$. Acesso em: novembro de 2017.

2. "Com público de 1 milhão, acaba ato de Nuno Ramos por mortos do Carandiru". In: Folha de São Paulo, 2/11/2016. Disponível em: http://www1.folha.uol.com.br/ilustrada/2016/11/1828761com-publico-de-1-milhao-acaba-ato-de-nuno-ramos-por-mortos-do-carandiru.shtml. Acesso em: novembro de 2017.

3. No Brasil, diante do encarceramento em massa da juventude negra e pobre do país, defendo que toda prisão é política. Alguns dados relevantes: $49 \%$ da população carcerária no Brasil tem entre 18 e 29 anos; $61,67 \%$ é negra e/ou parda; mais de $60 \%$ é analfabeta e/ou tem o ensino fundamental 
experiência prisional, em obras como Diário de um detento: o livro (2001), de Jocenir; Memórias de um sobrevivente (2001), de Luiz Alberto Mendes; e Sobrevivente André du Rap (do massacre do Carandiru) (2002), em co-autoria de André du Rap e Bruno Zeni, a que me deterei neste texto. ${ }^{4}$ As obras, de muitas formas, relacionam-se à produção da literatura de testimonio citada anteriormente, na medida em que tentam inscrever outras perspectivas históricas e silenciadas no contexto literário atual. Os sujeitos centrais nas obras são subalternizados, em geral, negros, pobres, sem escolarização completa, os quais, não tem garantido o acesso ao contexto de produção literária brasileira. Ou, mesmo quando têm, não conseguem construir uma carreira literária para além do papel de testemunhas da barbárie. Por exemplo, o caso de Carolina citado acima, em que a autora conseguiu se projetar, no momento da produção, como escritora, apenas quando apresentava o testemunho "de dentro da favela", mas a produção posterior não pareceu, no momento, interessar tanto a crítica. Tal questão que parece também relevante na continuidade da produção de André como escritor ou rapper, em Sobrevivente André du Rap.

De muitas formas, a importância de tais obras, me parece, deve ser lembrada, como afirma Penna (2009, p. 115), pois

[é] na existência carcerária, enquanto laboratório da pobreza brasileira, que encontraremos de forma literalmente concentrada a vida nua em sua versão contemporânea. É na prisão que normalidade anormal do estado de exceção que regula os bairros pobres, as periferias e as favelas do Brasil manifesta-se como um precedente jurídico para a vida fora do complexo penitenciário. Daí a importância dos testemunhos carcerários surgidos na sequência do massacre do Carandiru.

As produções artísticas reafirmam a importância do compromisso com a verdade e com a memória, além de se constituírem como documentos de denúncia social e de questionamento. $\mathrm{O}$ crítico ainda afirma que a relação que os textos literários fazem com os Lager nazistas não é por acaso, pois, de fato, as prisões brasileiras se constroem como "depósitos humanos", ou, nos termos de Loïc Wacquant, como "campos de concentração para pobres" (WACQUANT, 2011), o que é intensificado, em grande parte, para além do recorte de classes, pela estratificação etnorracial e pela discriminação baseada na cor. Escancaram, por outro lado, o que Pinheiro (1991) chama de um "autoritarismo socialmente implantado", ou seja, um autoritarismo que não termina com as ditaduras, mas que, ao contrário, sobrevive a elas e persiste nos aparatos da estrutura autoritária, que

incompleto. In: Brasil e sua população carcerária. Disponível em: http://www.politize.com.br/populacaocarceraria-brasileira-perfil/. Acesso em: novembro de 2017.

4. Cf. PALMEIRA, 2009. 
se mantém com as leis de exceção. Os pobres, miseráveis e indigentes (e adiciono indígenas, presos, entre outros) são aqueles que podem, de acordo com o autor, falar em uma manutenção penal da pobreza, a partir de um "ininterrupto regime de exceção paralelo" que sobrevive "às formas de regime, autoritário ou constitucional" (PINHEIRO, 1991, p. 48), ${ }^{5}$ a exemplo da recente operação da polícia militar na Rocinha, na cidade do Rio de Janeiro ${ }^{6}$.

De outra parte, além do boom da literatura carcerária, houve a expansão da perspectiva do testemunho - sobre a qual me referi no início do texto -, não apenas nos estudos literários ou culturais, ou do próprio gênero em si, mas de uma ampla perspectiva de escrita subjetiva. A crítica de Valeria de Marco (2004) ao que chama de uma extrapolação inicial do próprio conceito de literatura de testemunbo, que abarca gêneros e conceitos diferentes desde a escrita pós-Shoab, ou do testimonio latinoamericano, agora entende-se como uma própria "faceta da literatura" (MARCO, 2004), virada para o seu "teor testemunhal" (SELIGMANN-SILVA, 2010). Os produtos culturais na contemporaneidade podem, de acordo com Seligmann-Silva, ser lidos no seu teor testemunbal, ou seja, "não se trata de uma velha concepção realista e naturalista que via na cultura um reflexo da realidade, mas antes um aprendizado - psicanalítico - da leitura de traços do real no universo cultural" (SELIGMANNSILVA, 2008, p. 71). O teor se inscreve na materialidade literária, ou seja, na própria linguagem e na forma literária, de modo que reúne, em si, o presente e o passado traumático e desenvolve também a nossa própria capacidade de lidar com o traumático e de reescrever a história a partir de outro ponto de vista. Ao contrário do que parece ser uma "insistência" em uma normativa a respeito do gênero literário do testimonio (ou da literatura de testemunho), parece-me interessante pensar o gênero como algo mutável, moldável que se desloca ou que é deslocado ao longo do tempo e que se abre como nova possibilidade de leitura diante de uma era de tamanhas catástrofes. Nesse sentido, a literatura do cárcere apresenta uma nova construção possível para o(s) testemunho(s) e as suas formas de inscrição literária.

De acordo com a autora, ao se referir ao conceito,

[e]sta acepção do conceito de literatura de testemunho, por considerar uma grande flexibilidade quanto à forma do texto associada a uma natureza das experiências de aberto embate ideológico, abre a possibilidade de analisar uma tendência da produção literária latinoamericana do século XX em um contexto mais amplo, que ultrapassa os limites geográficos do

5. Cf. ARANTES (1964); AGAMBEN (2004).

6. Exército cerca Rocinha para conter guerra de traficantes no Rio. Disponível em: https://noticias. uol.com.br/cotidiano/ultimas-noticias/2017/09/22/ministerio-da-defesa-autoriza-cerco-doexercito-a-rocinha.htm. Acesso em: novembro de 2017. 
continente e aproxima-a à geografia mundial da barbárie, impondo a necessidade de examinar as relações entre violência, representação e formas literárias (MARCO, 2009, p. 51).

Diante de tais premissas, pretendo debater dois exemplos da literatura do/ sobre o cárcere, de teor testemunhal, os textos Sobrevivente André du Rap (2002), o qual narra, principalmente, o massacre do Carandiru e as experiências de André du Rap, sobrevivente do massacre; e Cela forte mulher (2003), o qual pretende apresentar as experiências de mulheres encarceradas na cidade de São Paulo. O objetivo, então, é discutir como os textos se estruturam e problematizam a mediação da alteridade radical entre intelectuais e detentos, seus impasses éticos e textuais, bem como refletir sobre a dificuldade em estabelecer uma (ou muitas) autoria(s) (ou autoridades/autorizações) diante de uma possível apropriação autoral da voz do outro. O que se coloca é a própria possibilidade de se pensar no conceito de representação a partir da voz do subalternizado, na esteira do pensamento de Gayatri Spivak (2010).

Os dois textos se incluem em uma perspectiva de particular interesse sobre tais testemunhos do cárcere, como disse, seja por parte da população ou da produção e crítica das artes, seja a partir de uma visibilidade midiática do massacre que capitalizou o interesse pela situação prisional e sinalizou para o mercado editorial tal demanda. Os dois livros que pretendo discutir foram publicados pela editora Labortexto, com o distanciamento de apenas um ano, que também editou o livro de Jocenir (2001) citado acima, assim como Quatrocentos contra um: a bistória do Comando Vermelho, de William da Silva Lima (1991). Ainda que, em um debate amplo, tais livros possam ser colocados lado a lado, as diferenças, principalmente na temática da mediação, são gritantes. As experiências dos mediadores, ou gestores do relato, bem como dos próprios presos, não são homogêneas e as construções, portanto, também não o são.

Os gestores do testemunho ou "narradores de ofício" são jornalistas, letrados, de classe média, que detém o registro do relato dos encarcerados. No caso específico de Bruno Zeni, definido ora como autor do texto Sobrevivente André du Rap (2002), ora como "coordenador editorial", a sua própria formação, no mestrado em Teoria Literária da Universidade de São Paulo, parece definir pressupostos a partir dos quais tenta questionar eticamente a estrutura anterior, de maneira a remodelar o gênero da literatura de testimonio para essa obra em específico.

É válido, ainda, ressaltar, que a autoria, nas duas obras, é considerada, ao menos na escrita dos livros em si, dupla, ou "a quatro mãos", como define o jornalista-autor de Cela forte mulber (2003). Ao mesmo tempo que narrador de ofício e autor não escolarizado formalmente vêm de contextos completamente diversos 
e apresentam experiências que não necessariamente se encontram, as suas relações estão completamente imbricadas, seja no próprio relato e na construção do livro, como também na própria experiência social. No livro, um depende do outro para inscrição e existência.

\section{SOBREVIVENTE ANDRÉ DU RAP (2002): A MEDIAÇÃO ENQUANTO FORMA}

O livro Sobrevivente André du Rap (do massacre do Carandiru) trata do relato de André, sobrevivente do massacre de 1992, sobre esse acontecimento, assim como sobre sua trajetória e vida; dos momentos de prisão, mas também de atuação como ativista pelos direitos humanos na liberdade. Bruno Zeni, mediador da obra, como mencionei anteriormente, conhece José André de Araújo (André du Rap) durante o testemunho formal perante a justiça paulista, enquanto Bruno cobria o evento como jornalista. A perspectiva de André perpassava o conhecimento de algo que testemunhou intimamente e do qual foi sobrevivente: o massacre do Carandiru. Nesse sentido, parece-me importante apontar que o termo "testemunho", em latim, refere-se a duas palavras diferentes: testis e superstes, como afirma Agamben (2008). O primeiro, testis, faz referência a um terceiro, um observador que pode testemunhar, restituir ou retratar, o que viu, a partir de perspectiva positivista de que poderia comprovar o acontecido perante um júri; o segundo, superstes, remete àquele que relata porque sobreviveu ao episódio traumático. Embora André seja superstes porque sobreviveu ao massacre, no momento em que é chamado para depor, incorpora as duas funções na medida em que pode também relatar o acontecido.

É interessante pensar também que, apesar do testemunho no julgamento, André sente a necessidade de contar, via escrita literária, o que lhe aconteceu, seja porque não acreditou nas possibilidades de resposta na via jurídica - também porque demonstra, na obra, a ineficácia da "justiça" em sua trajetória -, seja porque o próprio julgamento só conseguiu se dar na via da repetição traumática, invalidando e impossibilitando toda e qualquer decisão tomada e retomando, sempre que possível, o início dos julgamentos. Felman, em $\mathrm{O}$ inconsciente jurídico: julgamentos e traumas no século XX (2002), debate a relação dos julgamentos jurídicos com os eventos traumáticos e afirma que quando o direito tenta contar o trauma, o que prevalece é exatamente um domínio do evento traumático, que contamina o julgamento com uma espécie de "cegueira jurídica", a qual não se dá apenas na ordem do Direito, mas, principalmente, no âmbito social.

Por isso, o julgamento apenas reabre as inconscientes repetições do que é reprimido e recalcado pelas instituições jurídicas e pela própria cultura. Logo, o 
julgamento, em si, não consegue se encerrar, porque acaba sendo um próprio veículo de agravamento do trauma. A teórica analisa casos específicos, como o julgamento de O.J. Simpson e de Nuremberg, mas a interpretação que propõe parece se aplicar perfeitamente ao caso do Carandiru. Desde 1992, foram inúmeras tentativas de encerrar, pela via jurídica, o evento traumático, mas, em 2016, como já citado, foi decidido que seria necessário reabrir o caso, de maneira a inocentar os 74 policiais militares envolvidos e inicialmente condenados.

De acordo com Felman, a dimensão literária, com a linguagem do inacabado, do que é constantemente reaberto, teria a capacidade de responder ao que os julgamentos fecham: a elaboração (ou a tentativa de) dos eventos traumáticos. É esse também o trajeto de André du Rap: depois de testemunhar perante um juiz, conta a sua versão via literatura. Palmeira (2009) também demonstra como os presos decidem não apenas contar as suas histórias, mas tornarem-se autores de literatura. E esse processo de escrita se daria num sentido ético de transformação, de redenção e, mais do que isso, de acesso a outro lugar, outro espaço, que poderia retirá-los do estigma. Há uma ambiguidade, afirma Palmeira, entre estar "dentro" e "fora" do sistema. Usavam a escrita, a língua falada do outro, dos "homens livres", defende a crítica literária, para oporem-se ao sistema que tanto os oprimiu, mas, ao mesmo tempo, de dentro dessa língua do outro, "do inimigo", encontrarem-se, para além do estigma anterior. Seriam, agora, escritores, o que já na prisão tinha certo valor.

André encontra-se nesse lugar agora de testemunhar na via literária também como resposta à ineficácia da jurídica. Como afirma na obra, o seu relato tem como intenção "alertar a sociedade do que pode acontecer. Que o que aconteceu pode acontecer de novo. Um novo massacre. E muitas histórias que ainda continuam acontecendo, de injustiça, de preconceito, de desigualdade" (ARAUJO, 2002, p. 106).

De uma parte, parece haver proximidade formal com a literatura de testemunho latino-americana, ainda que não se trate de uma adaptação ou de uma continuidade. O próprio Zeni (2017), em texto recente, afirmou que a obra se liga, em muitos aspectos, à literatura de testemunho. Há um deslocamento temporal na medida em que reativa alguns procedimentos, como mostrarei a seguir, mas procura responder a questões problemáticas do tradicional gênero dos anos $60 \mathrm{e}$ 70. Bruno Zeni é um jornalista que conhece André, assim como Dantas ou Burgos, e decide tornar pública essa história. Ele já pesquisava literatura, escrevia e trabalhava em editora. Em um primeiro momento, é definido pela capa como "coordenador editorial", ao mesmo tempo em que, ao fim, há uma sessão intitulada "sobre os autores". Então, em uma co-autoria, Bruno demonstra, nas primeiras páginas, como 
se deu a construção do livro, como é dividido ("Depoimento", "Fragmentos de uma correspondência", "Free style [de improviso]" e "Aliados") e como as entrevistas se organizaram. A principal parte do livro, a primeira, é o resultado da transcrição das entrevistas feitas pelo jornalista com André du Rap, em 2001. Zeni ainda esclarece que:

[n]a edição do texto, procurei ser o mais fiel possível às particularidades da fala de André mantive inclusive suas incongruências e incorreções - por acreditar que não se pode separar a forma do conteúdo daquilo que se diz, se escreve ou se cria. [...]. Suprimi perguntas e outras intervenções que fiz durante nossas conversas (ARAUJO, 2002, p. 9).

Assim como o gestor do testemunho latino-americano, Zeni decide apagarse da entrevista e, ao sinalizar as formas de atuação, tenta manter-se transparente no relato. Ainda assim, as marcas dos diálogos estão postas em toda a entrevista, principalmente quando André parece prever o que não será compreendido na leitura - ou o faz porque é questionado pelo entrevistador, apesar de o leitor não ter acesso a tal informação -, explicando frases, contextos ou gírias, como em "moleque... moleque é como chamamos os homossexuais". Há momentos em que se dirige diretamente a Zeni, chamando-o à cena do testemunho do Massacre:

A cena era horrorizante. Começamos a lavar o pavilhão, puxando com rodo aquele momento de sangue. Pedaço de carne, pedaço de companheiro seu, pedaço de ser humano ali no meio da água misturada com sangue, sangue de vários homens. Vários companheiros se infectaram com doenças, todo mundo nu. Você imagina? (ARAUJO, 2002, p. 25, grifo meu)

A tentativa de apagar-se por parte do gestor é impossível. O texto final, bem como a escrita e elaboração da obra, torna Bruno também testemunha, ou seja, testemunha do testemunho do outro. Mais adiante, André está narrando a resistência perante os policiais e pergunta o que parece ser uma repetição dos questionamentos do coautor: "O que nós fizemos? Cada um tentou se proteger" (ARAUJO, 2002, p. 19).

$\mathrm{Na}$ editoração, a decisão de incluir o massacre nas primeiras páginas do relato, modificando a sequência da narrativa para que fosse o primeiro contato do leitor com o testemunho, é também de Bruno. O jornalista entendia como a obra seria conhecida e por quais motivos poderia tornar-se importante: o relato do massacre, principalmente.

A mediação atua, ainda, nos paratextos do testemunho de forma a garantir legitimidade. Insere, por exemplo, no meio do livro, uma série de fotos do sobrevivente. Comprovar quem foi André, o que fez, e como atuou, é importante para uma figura descreditada, vista como "bandida" perante a sociedade. Outro 
exemplo é a inserção de notas de rodapé que explicam ou reavaliam as afirmações que André fornece, incorporando, de acordo com Palmeira (2009), um discurso científico que quer esclarecer, comprovar, ou seja, garantir autoridade ao relato.

Em O que é um autor? (1969), Foucault, diante do debate da "morte do autor", tenta estabelecer o que permanecer dessa figura que seria exterior e anterior ao texto. Ainda que no testemunho não possamos falar de uma "morte do autor", exatamente porque é aí que essa figura se expõe de forma mais direta e complexa na escrita de si - alguns teóricos se referem, inclusive, ao "retorno do autor" diante do trauma $^{7}$-, Foucault estabelece que, no lugar da figura anterior, haveria uma "função autor", na qual o nome do autor assume um lugar central, o qual não é apenas "um elemento num discurso", mas assume "um certo papel em relação aos discursos: assegura uma função classificadora, concomitante" (FOUCAULT, 2009, p. 273). Continua:

[o] nome do autor funciona para caracterizar um certo modo de ser do discurso: para um discurso, o fato de haver um nome de autor, o fato de que se possa dizer "isso foi escrito por tal pessoa" ou "tal pessoa é autor disso", indica que esse discurso não é uma palavra cotidiana, indiferente, uma palavra que se afasta [...] mas se trata de uma palavra que deve ser recebida de uma certa maneira e que deve, em uma dada cultura, receber um certo status (FOUCAULT, 2009, pp. 273-274).

A figura do intelectual, aqui representada por Zeni, é quem garante a utilidade (e a importância) do nome da autoria e é quem permite certa legitimidade ou status. Na dupla autoria, cada um traz consigo o que pode, de maneira a formar um todo, não coeso, mas cheio de contradições que compõem a própria estrutura formal da obra. Diana Klïnger (2007) lembra que na atualidade não é possível reduzir a categoria de autor a uma função apenas. $\mathrm{O}$ autor atua e é percebido como sujeito midiático, se construindo e construindo-se no decorrer do relato. Para além disso, desde os anos setenta, afirma a autora, "com os debates pós-estruturalistas, feministas e pós-coloniais, devedores do pensamento de Foucault, não cessaram de retornar à pergunta pelo lugar de fala" (KLIÏNGER, 2007, p. 36) A pergunta que inicia o texto de Foucault (2009, p. 264) "Que importa quem fala?", se constitui como o princípio ético fundamental da escrita contemporânea.

Dessa forma, e incluído em tais debates, parece haver, por parte de Zeni, uma tentativa de diminuir a mediação ao mínimo, assim como de apagar-se de outras formas, de maneira a dar o espaço da voz e do relato, bem como da autoria, a André. Um exemplo é o trecho "Free Style", em que diz ter entregue um gravador a André para que desse depoimento sem a sua mediação, "de forma totalmente livre".

7. Cf. Klinger (2007) e Foster (2014). 
Em primeiro lugar, a entrevista primeira já havia acontecido e André, em muitos trechos, dirige-se ao que havia dito anteriormente (remetendo, inclusive, ao que Freud chama de "repetição traumática" ao lidar com os fatos relativos ao massacre), relatando novamente o que entendia que deveria ficar mais claro, ou, ainda, o que parecia ser uma interlocução com aquele que o ouviria depois. Em segundo lugar, é Bruno quem faz a seleção do áudio e a transcrição, mediando, novamente, o relato e o texto. Para além disso, o gravador media a fala e aquele que a escutará depois também. Há um contexto de produção específico. Mesmo no trecho "mais livre possível" - o que se percebe como um equívoco de interpretação -, a figura do intelectual marca a narração e a sua estruturação.

A decisão de deixar o seu texto final "Uma voz sobrevivente" - em que define os pressupostos teóricos da "coordenação editorial" - de fora do que seria a estrutura do livro, também falha. Parece-me louvável a tentativa de Zeni de atribuir a autoria a André, e apenas a ele, mas, ao mesmo tempo, a obra torna esse procedimento paradoxal, já que o texto faz parte do que se constituiu como livro. Palmeira (2009) afirma que, ao atribuir a autoria a André, tanto no texto, quanto na tentativa de retirada do seu próprio texto do que seria o livro, Zeni quer provar a possibilidade de olhar para esse livro e dizer que não lhe pertence, de maneira que pode, inclusive, dar seu juízo de valor para o que diz André e para a própria forma final do livro.

Na minha opinião, e de Palmeira (2009), a construção desse livro só pode ser entendida na imbricação de duas perspectivas completamente distintas, a partir de uma constituição híbrida. O livro se organiza exatamente diante do que Zeni chama de "duas alteridades radicais". A própria descrição em "sobre os autores" aponta para tal, em que temos André, negro, ex-prisioneiro, pobre, com ensino incompleto, morador da periferia da cidade de São Paulo e Zeni, intelectual, editor de livros, hoje doutor em teoria literária na Universidade de São Paulo e morador do bairro de classe média, Pompeia. Nos agradecimentos, são os dois que agradecem. São, então, os dois, testemunhas.

Palmeira ainda defende que o livro não pode ser entendido como "a convergência de duas urgências narrativas de origem diversa", mas traz em si a dualidade, pois não é uma só transcrição de entrevistas, assim como não se trata de uma autobiografia, ou uma biografia, caso Bruno falasse por André, mas é, antes, "um livro escrito a quatro mãos em que se fazem notar as contradições de cada um deles para dar forma à história de André" (PALMEIRA, 2009, p. 85) e, em certa medida, do registro do genocídio. Bruno, de alguma forma, empresta o seu nome, a sua posição social e, com isso, a legitimidade proposta pela hegemonia, para dar ao 
livro e a André, um espaço "no mundo dos homens livres". André, de outra parte, no seu relato, entende que caminha nessa fronteira. Consciente da mediação, no relato, volta-se para dentro, para a sua experiência, mas ao olhar para fora, atesta que a interlocução desconhece a sua realidade.

Recentemente, em um congresso da Associação Brasileira de Literatura Comparada (ABRALIC), Zeni (2017) discorreu sobre a experiência de mediação. Quase quinze anos depois, as problemáticas da formalização da experiência não se apagaram. Zeni explica algumas de suas escolhas novamente, como se colocam e como as defende agora. $\mathrm{O}$ autor explicita o apagamento de sua participação na mediação das entrevistas, mas entende que continua ali, gerindo-as, em todo o relato. André fala para esse interlocutor entendendo a sua posição e o que gerará tal relato. Os dois são conscientes da mediação e são modificados (pessoalmente e no relato) por ela.

Há, entretanto, "limites e dilemas", como afirma o jornalista. Depois da escrita do livro, a circunstância de "alteridade radical" se manteve. André esperava ter reconhecido o seu livro e a saída de uma posição subalterna na sociedade. De acordo com Bruno:

[e]ssa relação de alteridade radical [...] colocou certos dilemas de trabalho e da experiência que persistem. A inserção de Zeni nos meios editorais, intelectuais e mesmo de mercado de trabalho, já estava consolidada quando conheceu André. E deste era uma incógnita. Como ex-presidiário, sua inserção social era improvável, e o livro (e o rap e outros projetos que ele acalentava) poderia ter sido um caminho bem-sucedido. No entanto, as dificuldades de André permaneceram e ele não apenas não conseguiu um emprego estável como a vontade de gravar um disco de rap e de escrever um segundo livro não se concretizou.

No caso da obra Sobrevivente André du Rap, parece que a única perspectiva que importava do relato era o fato de ter sobrevivido ao massacre do Carandiru. As expectativas de futuro também não encontram espaço e André não consegue penetrar, de fato, no mundo livre. Não difere muito, inclusive, da experiência de Carolina Maria de Jesus, a que me referi anteriormente. A única experiência que agradava e importava o leitor "do lado de cá" era da favela. Dalcastagnè (2005) afirma que houve uma desatenção generalizada com a produção posterior, poemas, contos, romances, peças de teatro que não foram nem ao menos publicados, "como se a sociedade brasileira estivesse disposta a ouvir as agruras de sua vida, e só" (DALCASTAGNÈ, 2005, p. 68) - o que vem sendo modificado atualmente. Ou, ainda, como se não coubesse à mulher negra, catadora de lixo, escrever literatura, que cabe, ao fim, apenas àqueles que tem legitimidade social para tanto. Os livros servem enquanto documentos de uma realidade social e André só teve acesso à 
literatura quando teve ao seu lado alguém que já tinha acesso a tal mundo, da mesma forma como Carolina e Audálio Dantas.

A mediação, entretanto, não apaga nem diminui a importância de tais relatos, mas expressa o que continua, ainda na contemporaneidade - ainda que com melhoras, aumento de produções e editoras marginais e independentes, ou da produção própria de autores considerados marginais, como Ferréz e Vaz, por exemplo - sendo um problema do campo literário brasileiro e da nossa capacidade de ver e legitimar o que se constitui essencialmente fora.

A importância da obra não é questionável. Se fosse apenas pelo seu relato do Carandiru, já valeria. Como afirma Zeni, "este livro se pretende uma peça de resistência, dentro de um sistema que tem por norma excluir e massacrar, para que nada de semelhante ao que se fez no Carandiru em 1992 volte a acontecer" (ARAUJO, 2002, p. 218); André, por sua vez, assevera que "essa história tem que ser contada e não esquecida" (ARAUJO, 2002, p. 177). A lembrança, a dedicação e o agradecimento àqueles que foram mortos nas mãos de quem os devia proteger, por parte de André e de Zeni, marcam a literatura (e a sociedade) brasileira como uma herança essencial. Fica claro, também, o potencial e a capacidade de relato de André que, assim como Carolina, inscreve o seu nome no rol dos escritores. De outra parte, os relatos sobre a arbitrariedade do sistema judiciário e prisional, a denúncia às torturas - ainda tão presentes -, e a defesa dos direitos humanos que figuram no livro são, ao meu ver, aspectos que tornam a obra ainda mais relevante hoje. De acordo com André,

[o] que aconteceu no Carandiru foi uma crueldade. Nenhum ser humano merece aquilo. Estar num sistema qualificado como o pior do mundo e sair de lá morto... é um pedaço da minha vida e eu tenbo que estar aberto para falar disso. Foi um fato que aconteceu e está escrito na história do país (ARAUJO, 2002, pp. 26-27).

A palavra e o testemunho não são apenas uma forma de salvá-lo, como afirma em diversos trechos, mas salvam, a todos nós, da ignorância do acontecido e do apagamento histórico de tal tragédia coletiva.

\section{CELA FORTE MULHER (2003): A IMPOSSIBILIDADE DA MEDIAÇÃO}

O meu interesse inicial a respeito da obra de Antonio Carlos Prado surgiu pelo que ela se propõe em primeira instância: apresentar relatos de mulheres encarceradas sobre a sua experiência. O livro se inseria numa mesma linha editorial, já que foi publicado pela mesma editora de Sobrevivente André du Rap, apenas um 
ano depois. A perspectiva das mulheres do cárcere é pouquíssimo retratada na literatura, também testemunhal, apesar de haver uma produção crescente por parte de homens, como apresentei anteriormente. Esse livro parece ser um dos poucos exemplos desse tema. Diferentemente do anterior, no entanto, não parecer haver uma tentativa de releitura ou de aproximação teórica com a literatura de testimonio e, em certa medida, se constitui inclusive como uma espécie de "anti-testemunho". O livro constrói-se a partir da experiência de Antonio Prado - jornalista conceituado das grandes mídias do país - como voluntário nos cárceres femininos da cidade de São Paulo, de acordo com a narração do próprio autor. Ao contrário do que poderia parecer inicialmente, raras vezes Prado "cede a voz" ou a narração, às mulheres. O livro é dividido em sessenta e nove capítulos, os quais normalmente oscilam entre as histórias das mulheres e, principalmente, o contato e o diálogo delas com o jornalista, que se coloca como personagem central na obra. Apenas seis capítulos são iniciados e fechados com aspas, indicando a entrega da narração às mulheres. Assim como nos livros anteriores, há uma espécie de prefácio explicativo da obra, assinado pelo autor/mediador, mas ao contrário de Zeni, a definição da estrutura e do contato do mediador com as detentas é bastante reduzido e ocupa o espaço de apenas uma página, sem que se retome ao longo do livro. Nele consta que

[o] cenário é o sistema penitenciário feminino de São Paulo. Não particularizo locais para que as identidades das moças fiquem preservadas. Também por esse motivo todos os nomes foram trocados e as fotos, cuja publicação foi por elas autorizada (e como gostam de uma foto!) não são reveladas. Dou assim a cada uma das mulheres presentes neste livro o direito de aprontarem o que bem quiserem por essas páginas sem o risco de serem reconhecidas ou flagradas. As fotos elas viram e aprovaram. Um texto foi escrito do começo ao fim a quatro mãos dentro das celas e está creditado a quem de direito. (PRADO, 2003, p. 11).

Neste único trecho em que debate a mediação e a escrita, Prado defende que teriam sido, em primeiro lugar, as mulheres a pedir-lhe que escrevesse, e de outro, que teriam acompanhado e editado a escrita dos textos, ao longo do tempo em que foi um "escrevinhador", aspectos que não são marcados ou reforçados no decorrer do texto. $\mathrm{O}$ produto final, entretanto, em grande parte autocentrado, justificase como sendo feito "para elas" (PRADO, 2003, p. 11). A decisão de manter as identidades apagadas, sem nomeação e no obscurantismo, ao mesmo tempo que insere fotos das mulheres, parece contraditória. Por que seria necessário protegêlas da escrita, apagando o seu nome e o seu registro no livro, se, ao mesmo tempo, o autor mantém suas fotos? De outra parte, a afirmação de que o livro teria sido escrito "a quatro mãos" é, no mínimo estranha, pois, como relatei, são pouquíssimos os relatos em que Antonio Prado abre o espaço de relato direto. Como poderia haver uma "dupla autoria", nesse caso, se os capítulos se referem ao que o jornalista 
entende, percebe e narra, em última instância? Há capítulos e trechos inteiros em que o narrador descreve, do seu ponto de vista, o sistema prisional, as relações entre as mulheres, as formas e contrastes da experiência prisional, etc., mesmo que não viva essa experiência de fato, pois, como afirma, diferentemente delas, em um discurso discriminador, "não sou transgressor, nem estou preso [...] eu sou alguém que está na cadeia, solto" (PRADO, 2003, p. 53).

O fato de explicar o apagamento dos seus nomes não parece ter motivo aparente, pois não há, nem no relato das encarceradas nem no seu próprio, críticas mais severas à estrutura prisional ou judiciária, como há, por exemplo, em Sobrevivente André du Rap ou em Diário de um detento, entre outros. Não fica claro se o contexto de experiência prisional feminino é tão diferente do masculino, ou se há, deliberadamente, um apagamento da crítica. Ao fim do livro, por exemplo, só quem agradece é o próprio jornalista (no caso de Sobrevivente os dois autores agradecem). Nessa obra também fica claro o interlocutor a quem o livro se dirige, pois agradece, entre outros, ao Secretário Estadual da Administração Penitenciária de São Paulo, aos corregedores das penitenciárias, aos desembargadores e aos juízes, às diretorasgerais das instituições prisionais, às funcionárias das penitenciárias, aos advogados e aos psicólogos (PRADO, 2003, p. 191), em suma, ao sistema como um todo, recebendo méritos, sendo que, no relato de André, é alvo de crítica constante. Afirma, ainda, ser com esses braços do Estado com quem trabalha, como em "eu sempre tive a certeza, e ainda a tenho, de que ser voluntário não é jogar as presas contra as guardas e nem as guardas contra as presas, é preciso trabalhar em conjunto" (PRADO, 2003, p. 67). A única encarcerada a quem agradece chama-se "Scarlet", nome ficcional, sobre quem discorre em diversos trechos do livro.

Para além de narrador, Prado é o personagem central, não apenas do livro e da sua construção, mas do espaço prisional. $\mathrm{O}$ voluntário se coloca de maneira heroica em diversos trechos, como se, para além de "falar por elas" ou "dar voz às suas histórias", ainda conseguisse atuar dentro da penitenciária, melhorando as "transgressoras incorrigíveis". Em determinado capítulo, afirma que "sem falsa modéstia: algumas presas melhoraram em seus comportamentos transgressores dentro das próprias penitenciárias ou depois que saíram delas a partir da minha metodologia como voluntário" (PRADO, 2003, p. 170). Nesse mesmo capítulo, ao definir o seu papel diante de tais histórias, posiciona-se: "eu exproprio essas mulheres de suas histórias? Não. Eu me aproprio de suas histórias? Também não" (PRADO, 2003, p. 170). O jornalista, responde, ao fim, que

[e]u sou elas. Elas sou eu, já fizemos jornal e já montamos aquário, já organizamos festas, já rimos, já choramos, já tomamos chuva nos pátios. Tirei moça doente que estava sendo torturada em 
delegacia e a levei para o sistema penitenciário para ficar presa em companhia da irmã que já estava condenada (com a autorização do juiz corregedor da época), cuidei de queimadores, [...] levo-lhes medicamentos [...], levo-lhes livros e mais livros (PRADO, 2003, p. 170, grifo meu).

Logo, ele defende que opera apenas como mediador de uma história da qual elas são donas, sendo que tudo teria tido anuência das encarceradas e que teriam sido elas também que "pediram para esse trabalho ser feito", diante de um mediador cuja ética não pode ser de nenhuma maneira questionada, pois nunca "cometi um desvio, nunca as desrespeite como mulheres, nunca deixei de ser cavalheiro" (PRADO, 2003, p. 171). O lugar que ocupa, entretanto, é marcado pela (re)afirmação constante da sua posição de classe e pela marcação de que não é transgressor e não está preso, ao contrário delas. A proposição marca a moral superior do mediador, já que não desvia, não erra, e ao fim, não está preso. Em determinado momento, por exemplo, afirma que teve a ideia de criar um jornal no cárcere em um restaurante que sempre frequenta no centro de São Paulo, no qual come o mesmo prato, senta-se na mesma mesa e é atendido e conhecido por um maître específico. O jornal, entretanto, não continua por falta de auxílio para xerocar os exemplares. Contraditoriamente, no entanto, o jornalista afirma que o fim não teria sido causado pela falta de interesse ou de incentivo, já que "guardas, diretoras e presas ficaram tristes" (PRADO, 2003, p. 101) com o seu fim.

Entretanto, a definição que ele apresenta das mulheres é marcada, assim como no discurso judiciário, pelo crime que cometeram. O narrador refere-se a elas como "a presa psicótica", "a matadora de aluguel", "a sequestradora", "a estupradora", entre outros. Seguindo uma lógica sensacionalista, os crimes hediondos são privilegiados em sua escrita, ainda que saibamos que grande parte da população feminina carcerária no Brasil tenha sido condenada por crimes relacionados ao tráfico ou roubo, enquanto uma minoria de $6 \%$ teria cometido homicídio, por exemplo. ${ }^{8} \mathrm{O}$ discurso sobre o outro é o mesmo que as circunscreve no sistema prisional. Não são mulheres, mães e irmãs, mas são rotuladas pela transgressão cometida. Há diversos trechos inclusive que tenta saber das mulheres se "sentem-se arrependidas" ou "culpadas" pelo que fizeram. Atua, assim como a justiça, em um discurso que intensifica a culpabilização e individualiza questões que muitas vezes são reflexos de condições sociais, por exemplo em dois diálogos que trava com as mulheres. No primeiro, a personagem Gilda afirma ter matado ao roubar. O diálogo questiona sobre a culpa que teria sentido: " - E não sente culpa? - Nenhuma. Nunca senti culpa. [...] - O que leva alguém a transgredir

8. Cf. "Brasil e sua população carcerária". Disponível em: http://www.politize.com.br/populacaocarceraria-brasileira-perfil/. Acesso em: novembro de 2017. 
a lei? - Outra bobagem. Desista de tentar entender" (PRADO, 2003, p. 51). O narrador persiste na culpabilização e não se questiona, em nenhum momento, porque não consegue entender, ou ao menos porque a personagem evidencia e reforça a sua incapacidade. Em outro momento, questiona Lupércia se ela se arrepende de ter participado dos crimes do marido. Quando a resposta é negativa, Prado responde "- mas você podia ter impedido. A verdade é que você ajudava no estupro" (PRADO, 2003, p. 87). A obrigatoriedade de discutir os seus crimes e de ser apontadas como criminosas, mesmo por um voluntário, e principalmente pelo sistema judicial é parte da construção da narrativa e atua na manutenção de uma mesma lógica do sistema judicial e carcerário. A narração não sai, portanto, do discurso hegemônico sobre as detentas.

A questão de raça é também apagada na narrativa. Apesar de se tratar de população carcerária, a qual no Brasil é majoritariamente negra - como apresentei nos dados anteriores - e tal aspecto ser central no relato de André, em Sobrevivente, por exemplo, nesta narrativa o autor nem ao menos menciona a questão e nem apresenta, no relato das mulheres, qualquer problematização a esse respeito. Há nas fotos, entretanto, uma série de mulheres negras no contexto colocado.

Há, ainda, outra questão extremamente complicada na construção da obra: a constante referência ao papel de gênero como estabelecido pelo patriarcado, na medida em que reforça o estereótipo destinado às mulheres de que são sensuais, sedutoras ou "imantadas". As imantadas, define o narrador, seriam as mulheres cuja arma principal é a lábia e o poder de sedução. Para ele, além de não terem sentimento algum de culpa e o prazer de causar sofrimento psicológico e físico, levam, em alguns casos, os homens a transgredir (PRADO, 2003, p. 15). Elas "transformam a vida de quem se aproxima delas num jogo de sedução e transgressão, mais atraente e mais desesperador quanto maior o grau de encantamento e paixão de quem se deixa seduzir" (PRADO, 2003, p. 15). Elas ainda são uma tentação, dependem de um "convite" para entrar em suas vidas, que o narrador parece aceitar. Na relação de "sedução", há um diálogo bastante elucidativo:

- Ainda vou sequestrar você.

Eu me senti meio paquerado, meio ameaçado. Fiquei com medo mas gostei. [...]

- Me sequestrar, Scarlet? Só se você tomar conta do cativeiro.

Ela me olhou fundo nos olhos:

- Mas é isso mesmo o que eu gosto de fazer (PRADO, 2003, p. 30).

Em outro trecho, o narrador, em um discurso que imbrica o estereótipo feminino, certa essencialização de gênero e a vontade de inscrição das mulheres como servis aos desejos masculinos, explicita: 
Essas mulheres são do palco, eu sou da plateia. Por isso sei que elas merecem rodar bonitas para mais gente, porque tire-se tudo delas, espelho, coxia, camarim, maquiagem e toucador, tire-se a possibilidade da vaidade, tire-se a vontade de variar de cores, tirem-se brincos e pulseiras, presilhas e gargantilhas, vestido, saia e salto alto, tire-se até o uniforme bege e branco, deixemo-nos nuas e ainda assim algo resistirá inconsútil: o ser mulher. (PRADO, 2003, p. 49, grifo da autora).

No texto A outra questão, Homi Bhabha (1998) discute como o estereótipo atua no contexto colonial, especialmente nas relações de raça. Nesse contexto, a diferença é construída como aparato de poder e tem como objetivo apresentar o colonizado como um tipo "degenerado", cuja própria condição justifica a dominação. O estereótipo não só impede de ver para além da diferença, como garante uma forma de atuação violenta sobre o outro, ainda que ambivalente. As alteridades se constroem ao mesmo tempo como objeto de desejo e de escárnio e como passíveis de apreensão. Para Bhabha, não podemos apenas rejeitar o estereótipo, mas pensar de que formas as alteridades são construídas no discurso e como se perpetuam neles. No caso de Cela forte multher, por exemplo, o narrador se aproxima e se distancia das mulheres a todo momento. Às vezes, identifica-se com elas, ao mesmo tempo que deixa clara a sua posição privilegiada. São objeto de desejo e de admiração, mas são, ao mesmo tempo "transgressoras" sem nenhuma espécie de sentimento de arrependimento ou de culpa e passíveis de cometer os mesmos erros e crimes. O crítico pós-colonial lê o conceito do estereótipo relacionando-o com o fetichismo, porque envolve de uma parte um fascínio, ou desejo, ao mesmo tempo que o rejeita,

[i]sto porque o fetichismo é sempre um 'jogo' ou vacilação entre a afirmação arcaica de totalidade/similaridade [...] e a ansiedade associada com a falta e diferença [...] Dentro do discurso, o fetiche representa o jogo simultâneo entre a metáfora como substituição (mascarando a ausência e a diferença) e a metonímia (que registra contiguamente a falta percebida). O fetiche ou estereótipo dá acesso a uma 'identidade' baseada tanto na dominação e no prazer quanto na ansiedade e na defesa, pois é uma forma de crença múltipla e contraditória em seu reconhecimento da diferença e recusa da mesma (BHABHA, 1998, p. 116).

Não é um problema, portanto, apenas porque é uma falsa representação da realidade, mas porque seria "uma forma presa, fixa, de representação que, ao negar o jogo da diferença (que a negação através do Outro permite), constitui um problema para a representação do sujeito em significação de relações psíquicas e sociais" (BHABA, 1998, p. 117). bell hooks, em seu texto "Eating the other: desire and resistance" (1992) - no qual debate, principalmente, a questão de raça nos Estados Unidos -, também discorre sobre como o deslocamento em direção ao outro, muitas vezes, se constitui, na verdade, como experiência de prazer. O "outro" ou o "diferente" se torna mercadoria e seduz exatamente pela sua diferença. Ainda que a 
capacidade de ver o outro seja vendida como uma possibilidade de reconhecimento ou de reconciliação, para a teórica, o desejo, ou a vontade de apreensão, muitas vezes auxilia ainda mais a manutenção do status quo. A narrativa que se cria do outro, diz hooks (1992), é aquela que satisfaz o meu desejo e que garante a manutenção dele na diferença e na alteridade. A sua história, o seu passado, a sua herança e/ou os seus desejos (do outro) são descontextualizados e consumidos canibalisticamente.

Para a autora, é chegada a hora de questionarmos determinadas imagens, para que não haja uma continuidade:

[o] principal medo é que as diferenças culturais, étnicas, e raciais sejam continuamente mercantilizadas e oferecidas como novos pratos para potencializar o paladar branco - no qual

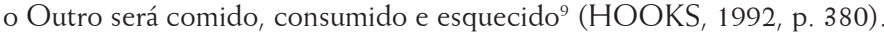

A manutenção, então, das mulheres, por parte do narrador, no lugar do outro estereotipado e objeto de desejo, as mantém no obscurantismo, mas, além disso, na lógica do discurso de poder e do patriarcado. Não há possibilidade de saída do estereótipo, por parte do mediador, no livro. Para além da mediação clássica, a que nos referimos como problema muitas vezes, a obra parece impossibilitar a mediação porque, no fundo, não escuta. A autoria é sua, bem como a autoridade, não apenas de escrita, mas ética e moral, no caso de Prado.

A resposta negativa e categórica de Spivak (2010) à questão "pode o subalterno falar?" parece responder ao texto de Prado. A partir do texto Os intelectuais e o poder, de Deleuze e Foucault, a teórica critica o papel dos intelectuais em sua dificuldade de perceber como os seus discursos, em nome do subalterno, estão imbricados no discurso hegemônico. $\mathrm{O}$ ensaio denuncia tanto o intelectual que acredita poder falar sobre o outro e construir seu discurso de resistência a partir de tal crença, quanto o que afirma que o outro dispensa sua mediação, o que faz com que mantenha as estruturas de poder e de opressão e continue praticando o mesmo ato de silenciamento que denuncia. $\mathrm{O}$ subalterno, esse que não tem agência e nem espaço de ação reconhecidas, não consegue falar por si mesmo porque não há escuta possível. A voz do subalterno acaba por ser mediada por alguém que se coloca na posição de reivindicar algo em nome deste outro. De toda a condição de subalternidade, no entanto, seria o sujeito subalterno feminino aquele "que está ainda mais profundamente na obscuridade" (SPIVAK, 2010, p. 85). Spivak defende que:

9. Tradução da autora. Trecho original: "[t] he over-riding fear is that cultural, ethnic, and racial differences will be continually commodified and offered up as new dishes to enbance the white palate - that the Other will be eaten, consumed, and forgotten". 
[e]ntre o patriarcado e o imperialismo, a constituição do sujeito e a formação do objeto, a figura da mulher desaparece, não em vazio imaculado, mas em um violento arremesso que é a figuração deslocada da 'mulher do Terceiro mundo', encurralada entre a tradição e a modernização. (SPIVAK, 2010, p. 160).

A mulher subalternizada - sujeito duplamente subalternizado - então, não consegue ser ouvida ou lida (ou editada aqui) e diante da violência dos apagamentos pelo patriarcado, é responsabilidade do intelectual perceber o seu papel nesta prática.

\section{CONSIDERAÇÕES FINAIS}

O papel da literatura na representação cultural não pode ser ignorado. A crítica ao que é "a literatura", essa que defende um cânone ocidental, branco e masculino, perpassa, de um lado, o reconhecimento de que o "centro" ou o "cânone" se mantém e depende das margens e dos marginalizados para existir; e de outro, a compreensão de que sem a abertura (e a exigência de uma abertura) desse campo, que considere as vozes marginalizadas como produtoras de textos literários, não será possível criticar esse lugar e se fazer ouvir. Não basta "dar voz", pois a voz já existe, mas escutá-la, reconhecer a sua importância e legitimidade. De acordo com Regina Dalcastagnè (2002), os impasses da representação literária não se resumem ao eminente lugar de fala, mas indicam a importância da democratização da produção literária, vinculada, claro, à democratização social. Os questionamentos dizem respeito a importância de outros textos que gerem uma "contaminação pelo olhar do outro", uma abertura para valores diferentes dos nossos, uma atenção aos preconceitos embutidos, um questionamento sobre o que era visto como dado, ou seja, uma consciência do problema que possa gerar um debate e uma crítica honesta. O fazer literário precisa ser revisto.

A questão central de Spivak (2010), no livro publicado em 1985, me parece ainda fundamental, na questão da mediação. Ainda hoje, a (im)possibilidade de escuta do subalterno é questionada. Para lidar com isso, entretanto, não existem respostas fáceis, mas tentativas, algumas mais empenhadas que outras, como tentei demonstrar. A tentativa de mediação na literatura, por parte do intelectual, apresenta contradições, porque socialmente, historicamente e economicamente as contradições não foram nem serão tão facilmente resolvidas, e aí reside o silêncio continuado do subalterno. Se no caso de André du Rap, para além das contradições da própria mediação, a subalternidade se manifesta, após a recepção da obra, na impossibilidade de adquirir o título de escritor e a autoridade da autoria, no caso 
das mulheres de Cela forte mulber, a própria forma de inscrição já as subalterniza. Me parece que o importante, nesses impasses e negociações entre gestor e testemunho, é a consciência das dificuldades e da impossibilidade de escondê-las, e a vontade de uma ética do olhar e ouvir o outro, como me parece ser o exercício que Bruno Zeni, por exemplo, parece levar mais a sério.

A potência de uma escrita testemunhal, no entanto, a exemplo da obra de Araujo e Zeni, não é diminuída por essas contradições. O caso do Carandiru, por exemplo, se constrói simbolicamente e culturalmente, no imaginário brasileiro, porque existiram tentativas de mediação, e isso não é pouco. Em ensaio crítico sobre a obra Elizabeth Burgos e Rigoberta Menchú, com o qual iniciamos, Penna (2003) defende que prefere permanecer fiel aos temas básicos do testemunho e às possibilidades que ele abre, ainda que este não se realize exatamente como se desejava:

[m]as quem sabe não o corpo, a dor ou a fome que os críticos do testemunho esperavam e desejavam, mas a política de escuta desses corpos sentindo dor e com fome, que continuamos tendo que atestar, apesar de por causa deles não provocarem a prática e a ação que projetávamos sobre eles, que queríamos que eles realizassem por nós, para redimir o nosso desejo restitutivo culpado, mas que, confirma a nossa culpa, e sem resolvê-la, acusa sempre a nossa culpa irrevogável, o testemunho não deixa de contar. Essa é e continua sendo o real do testemunho (PENNA, 2003, p.346).

\section{REFERÊNCIAS}

AGAMBEN, G. (2008). O que resta de Auschwitz: o arquivo e a testemunha. Tradução de Selvino J. Assman. São Paulo: Boitempo.

ARAUJO, J. A. de. (2002). Sobrevivente Andre du Rap: (do massacre do carandiru). Coautoria de Bruno Zeni. São Paulo, SP: Labortexto.

ARANTES (2010). O ano que não terminou. In: TELES, Edson; SAFATLE, Vladimir (Orgs.). O que resta da ditadura: a exceção brasileira. São Paulo: Boitempo.

BHABHA, H. (1998). A outra questão. O estereótipo, a discriminação e o discurso do colonialismo. In: BHABHA, Homi K. O local da cultura. Trad. Myriam Avila, ELiana Lourenço de Lima Reis, Glácia Renate Gonçalves. Belo Horizonte: Ed. UFMG.

BURGOS, E. (1993). Meu nome é Rigoberta Mencbú: e assim nasceu minha consciência. Tradução de Lólio Lourenço de Oliveira. Rio de Janeiro: Paz e Terra.

BUTLER, J. (2004). Precarious life: the powers of mourning and violence. London: Verso. 
BUTLER, J. (2015). Quadros de guerra: quando a vida é passível de luto? Tradução de Sérgio Tadeu de Niemeyer Lamarão e Arnaldo Marques de Cunha. Rio de Janeiro: Civilização Brasileira.

CORONEL, L. P. (2015). A terceira margem de Carolina Maria de Jesus. In: FARIA, A.; PENNA, J. C.; PATROCINIO, P. R. T.. Modos da margem: figurações da marginalidade na literatura brasileira. Rio de Janeiro: Aeroplano.

DALCASTAGNÈ, R. (2005). "Isso não é literatura (sobre Carolina Maria de Jesus e Paulo Lins)". In: DALCASTAGNÈ, Regina. Entre fronteiras e cercado de armadilhas: problemas da representação na narrativa brasileira contemporânea. Brasília: Editora Universidade de Brasileira: Finatec.

DALCASTAGNÈ, R. (2002). Uma voz ao sol: representação e legitimidade na narrativa brasileira contemporânea. In: Estudos de literatura brasileira contemporânea, n. 20, p. 3370. Disponível em: http://periodicos.unb.br/index.php/estudos/article/view /221 4. Acesso em: maio de 2017.

FELMAN, S. (2014). O inconsciente jurídico: julgamentos e traumas no século XX. Tradução de Ariani Bueno Sudatti. São Paulo: EDIPRO.

FOSTER, H. (2014). O artista como etnógrafo. In: FOSTER, Hal. O retorno do real: a vanguarda no final do século XX. Trad. de Célia Euvaldo. São Paulo: Cosac Naify.

FOUCAULT, M. (2009). O que é um autor?. In: FOUCAULT, Michel. Estética: literatura e pintura, música e cinema. Organização Manoel Barros da Motta; Tradução Inês Autran Dourado Barbosa, 2 ed.. Rio de Janeiro: Forense Universitária.

HOOKS, b. (1992). Eating the Other: Desire and Resistance. In: Black Looks: race and representation. p. 21-39. Boston: South End Pres.

JESUS, C. de. (2014). Quarto de despejo: diário de uma favelada. São Paulo: Ática.

KLINGER, D. (2007). Escritas de si, escritas do outro: o retorno do autor e a virada etnográfica: Bernardo Carvalho, Fernando Vallejo, Washington Cucurto, João Gilberto Noll, César Aira, Silviano Santiago. Rio de Janeiro: 7Letras.

MARCO, V. de. (2004). A literatura de testemunho e a violência de Estado. Lua Nova, São Paulo, n. 62, p. 45-68. Disponível em: http://www.scielo.br/scielo .php?script=sci arttext\&pid $=$ S0102-64452004000200004\&lng $=$ en\&nrm $=$ iso. Acesso em: novembro de 2017. 
PALMEIRA, M. R. S. Soares. (2009). Cada história, uma sentença: narrativas contemporâneas do cárcere brasileiro. Tese (Doutorado em Literatura Brasileira) - Faculdade de Filosofia, Letras e Ciências Humanas, Universidade de São Paulo, São Paulo. Disponível em: http://www.teses.usp.br/teses/disponiveis/8/8149/tde06092011-142127/pt-br.php. Acesso em: outubro de 2017.

PENNA, J. C. (2003). Este corpo, esta dor, esta fome: notas sobre o testemunho hispanoamericano. In: SELIGMANN-Silva, Márcio (org.). História, memória, literatura: o testemunho na Era das Catástrofes. Campinas, SP: Editora da Unicamp.

PERPÉTUA, E. D. (2014). A vida escrita de Carolina Maria de Jesus. Belo Horizonte: Nandyala.

PERPÉTUA, E. D. (2002). Produção e recepção de Quarto de despejo de Carolina Maria de Jesus: relações publicitárias, contextuais e editoriais. In: Em tese. Belo Horizonte, v.5, p.33-42, dez. 2002.

PINHEIRO, P. S. (1991) Autoritarismo e transição. In: Revista USP. São Paulo: Editora Universidade de São Paulo. Disponível em: http://www.revistas.usp. br/revusp/ article/view/25547/27292. Acesso em: agosto de 2016.

PRADO, A. C. (2003). Cela forte mulber. São Paulo: Labortexto Editoria.

SELIGMANN-SILVA, M. (2006). Novos escritos dos cárceres: uma análise de caso. Luiz Alberto Mendes, Memórias de um sobrevivente. In: Estudos de literatura brasileira contemporânea. Brasília. n. 27, pp. 35-58.

SELIGMANN-SILVA, M. (2010). O local do testemunho. Tempo e argumento. Florianópolis: UDESC, v.2, n.1, p.3-20, junho de 2010.

SPIVAK, G. C. (2010). Pode o subalterno falar?. Tradução de Sandra Regina Goulart Almeida, Marcos Pereira Feitosa e André Pereira Feitosa. Belo Horizonte: Editora UFMG.

WACQUANT, L. (2011). As prisões da miséria. Tradução de André Teles. Rio de Janeiro: Zahar.

ZENI, B.; TIMERMAN, N. (2017). A escrita e a prisão: potências e dilemas. Anais da ABRALIC. Rio de Janeiro: UERJ, pp. 305-314.

Recebido: 12/12/2017

Aceito: 09/07/2018 